ISMGE 2020

II International Scientific and Practical Conference "Individual and Society in the Modern Geopolitical Environment"

\title{
NEOLOGIZATION OF MANAGEMENT ACTIVITY LEXIS IN THE MODERN OSSETIC LANGUAGE DURING COVID-19
}

\author{
Larisa Gatsalova (a)*, Larisa Parsieva (b) \\ *Corresponding author \\ (a) Vladikavkaz Scientific Centre of the Russian Academy of Sciences, 22, Markusa street, Vladikavkaz, 362027, \\ Vladikavkaz, Russia, larabella8@mail.ru \\ (b) Vladikavkaz Scientific Centre of the Russian Academy of Sciences, 22, Markusa street, Vladikavkaz, 362027, \\ Vladikavkaz, Russia, parsieva_larisa@mail.ru
}

\begin{abstract}
This article deals with issues related to active processes occurring in the vocabulary and terminology of document support of management based on the material of the modern Ossetic language. Ossetians are a relatively small people (about 700,000 people worldwide), and the number of speakers of this language is decreasing every year. To change this situation, Ossetia has adopted a government program of national and cultural development aimed at supporting the language and expanding its functional capabilities. The activities of this program include inventory, ordering, classification of the nomenclature of terms for document support of management, creation of standard documents of various types, dictionaries and reference books that contribute to the development of the functioning of the Ossetic language in the official sphere, training of public servants and public officers in modern business Ossetic language. For all these activities is the first step to conduct research work to describe the capabilities of the vocabulary of the language to service the field of document management and document support of management, to select and systematize terms, to study the word-formation potential of the modern Ossetic language in both its ironskiy and digorskiy dialects, to create cliched forms and turns to unify standard documents and eliminate difficulties in compiling unconventional forms. The identification of general trends in the neologization mechanism of the document management language seems to be a fairly necessary procedure in this situation. To date, there have been no such studies in Ossetian studies, and this article partially fills this gap.
\end{abstract}

2357-1330 C 2020 Published by European Publisher.

Keywords: COVID-19, lexicology, management documentation, Ossetian language, pandemic, terminology. 


\section{Introduction}

One of the most relevant topics for the national languages of the small-numbered peoples of the Russian Federation remains the formation, normalization, and development of terminological systems to expand the functionality of these languages, to overcome the lag in the vocabulary of the language compared to Russian, which the bilingual society knows much better.

Russian is threatened by the total borrowing from English, which currently dominates the world, but for the titular ethnic groups of the national constituent entities of the Russian Federation, this source is the state language, which is used for all document support, and which serves all spheres of activity, namely, Russian.

In recent years, specialists in the Ossetic language have been carrying out several activities that have significantly improved the potential of the language's functioning to supplement the terminological systems in various fields of activity (Senko, 2019a). Terminological and translation dictionaries were published, which significantly expanded the vocabulary of the Ossetic language. They reflect both the industry terminology that has existed up to now and the new terminology that has emerged as a result of the development of science and technology, as well as modern socio-political and cultural processes. There are positive trends in how neologisms are introduced into the Ossetic language. If up to this time new words and combinations were mainly represented by borrowings, then in new lexicographic publications we see more lexical units formed by the means of the language itself (Senko, 2019b).

\section{Problem Statement}

In general, the terminology of document management in Ossetian linguistics remains one of the least developed problems, so the study of active processes occurring in this term system is relevant. There are very few special works devoted to the issues of document linguistics, management terminology, and office dictionaries. The authors of this article considered this topic in a series of publications on terminology, in particular, they described the innovations that appeared in the Ossetic language in the sphere of related management activities - socio-political, economic, legal. We also devoted a more detailed lexis analysis of archives and records management to the work "Lexis of management activity in the Ossetic language" (Gatsalova \& Parsieva, 2019). For the first time, about three hundred terms of the mentioned branch were put into circulation for the Ossetic language.

\section{Research Questions}

Despite the recent upsurge in Ossetian lexicography, including the one that reflects the terminology resources of the language, document management remains the branch with the least attention paid to the term system.

The press is published in the Ossetic language are created fiction books. Ossetians widely use their native language in virtual communication in social networks.

The vocabulary study that has left the framework of non-usual use and has become a currency and relevant is especially representative of the material of media discourse (Gureeva et al., 2016; Mityagina, 2014; Novozhilova et al., 2015). The current status of speech culture both Russian and Ossetian 
languages are determined by several mutually dependent factors, primarily extralinguistic since language is a socio-cultural code that reflects the state of society and its world picture. This picture is most clearly projected by the vocabulary is the most mobile language structure (Ilyin \& Sidorova, 2019; Ilyin \& Solomka, 2018; Isaeva \& Isaev, 2010; Morgoeva \& Tsallagova, 2018; Morgoeva \& Tsallagova, 2019; Tsopanova et al., 2019). The identification of language use and its frequency indirectly, but accurately shows us the whole picture of social, cultural, economic, and political changes currently taking place in a particular society (Gatsalova \& Parsieva, 2015). The management area is a fairly open system that depends on the transformations taking place in society that is directly related to the regulation of the activities of government services, executive and legislative authorities in society (Kudzoeva, 2014).

\section{Purpose of the Study}

This research aims to solve several problems relevant to modern Ossetian linguistics. The authors define the corpus of words and phrases missing in lexicographical publications with the meaning of the name of a person, position, authority or institution, historical event or an official holiday, etc., describe a significant number of clerical and cliched expressions of the official style of speech in the Ossetic language. Special attention is paid to recent trends - the introduction of words and lexical phrases into the Ossetic language, which appeared during the COVID-19 pandemic

\subsection{General purpose of the study}

In a broader context, the study suggests solving the question of the possibilities of the Ossetic language when using it as a means of document support of management and document management, whether it has enough lexical and derivational potential to serve the official style.

\subsection{Specific tasks of research}

In a narrow sense, the purpose of this study is:

- identification of words and lexical phrases related to the field of document support of management in the Ossetian media space;

- classifying them by thematic feature;

- the definition, among them neologizing units;

- content analysis of the Ossetian-language media space during the COVID-19 pandemic and identification of neologisms of the latest period.

Fixing new lexical items is of great importance for updating dictionaries of neologisms, translation and defining dictionaries, terminological dictionaries of specific industries. Recently, the vocabulary of document management can be distinguished by novations that are actively used in the usual field of the language.

\section{Research Methods}

The study uses the following different methods of analyzing linguistic material: comparativehistorical, comparative, content analysis, descriptive, and continuous sampling method. 


\section{Findings}

Let's consider the main trends in active processes occurring in the lexical system of the Russian and Ossetian languages of the modern stage, which can be characterized by its socio-cultural characteristics as a pandemic period. Global changes taking place all over the world, in one way or another, affected absolutely every individual, affected the socio-economic and cultural aspects of society. Therefore, language is a mirror that reflects all the transformations taking place in society has shown its activity and flexibility, becoming a tool for effective communication in a difficult historical period. This mobility is best seen in the example of media discourse, the content of which has become the material for this research. As the most characteristic for detecting changes occurring at the lexical level in modern Russian and Ossetian languages, we studied the media sites of the Republic of North Ossetia-Alania-the newspaper "Рæстдзинад", the national television "Ossetia-Iriston", the website of the South Ossetian newspaper "Хурзæрин", the news feed Mail.ru and Yandex.ru, social networks Instagram and Facebook.

The study revealed that the business Ossetian language includes words and stable collocation that are not reflected in the currently available dictionaries, since they appeared in the language relatively recently, as well as phenomena, concepts, and objects that they denote (Senko, 2019c). For example, the Republican Ossetian-language Newspaper "Рæстдзинад" (2020, May 29; 2020, June, 5) uses the following innovations (we specify them by thematic groups integrated with the document management field):

\section{State and municipal government:}

- in pursuance of the may decrees: "УФ-йы Президенты Майы указтæ æххæст кæныны фæлгæты";

- national project "национ проект";

- to submit for discussion "æркæсынмæ бавдисын";

- minimum level of subsistence "фæцæрынæн чи хъæуы, æппынкъаддæры уыцы бæрц";

- municipal unit "муниципалон сконд";

\section{The names of the public servants:}

- Auditor of the Chamber of Control and Accounts "цæстдарæн-нымайæн палатæйы аудитор";

- Deputy Minister of Foreign Affairs of the Russian Federation "Уæрæсейы Федерацийы фæсарæйнаг хъуыддæгты министры хæдивæг";

- Deputy Prime Minister of the Russian Federation "Уæрæсейы Федерацийы Хицауады Сæрдары хæдивæг";

The envoy from the President of the Russian Federation in the North Caucasian Federal district "Уæрæсейы Федерацийы Президенты Æххæстбарджын минæвар Цæгат Кавказы федералон зылды";

- Plenipotentiary representative of the Russian Federation in Saudi Arabia, "Саудаг Аравийы Уæрæсейы Федерацийы Æххæстбарджын минæвар"; 
- Chairman of the Parliament of the Republic of North Ossetia-Alania "Республикæ Цæгат Ирыстон-Аланийы Парламенты Сæрдар";

- Members of the Cabinet Minister "хицауады кабинеты уæнгтæ", etc.;

The next group of novations "Names of organizations, departments, regulatory and administrative authorities" is very heterogeneous in its semantic composition, so we have divided it into subgroups.

\section{The names of international organizations:}

- World Health Organization "Æнæниздзинад хъахъхъæнынады дунеон организаци";

- Parliamentary Assembly of the Council of Europe "Европæйы Советы Парламентон ассамблей";

- International Labour Organization (ILO) "Фæллойы æппæтдунеон организаци (ФÆО)";

- Economic Commission for Europe (ECE) "Европæйы экономикон къамис";

- International Organization for Standardization (ISO) "Стандартизацийы æппæтдунеон организаци";

\section{The names of federal and local authorities:}

- The autonomous non-profit organization "Development center of folk artistic crafts", "Автономон æнæкоммерцион организаци "Адæмон аивадон промыселты рæзты центр";

- Executive Office of the Government of the Russian Federation "Уæрæсейы Федерацийы Хицауады Аппарат";

- State Duma of the Federal Assembly of the Russian Federation "Уæрæсейы Федерацийы Федералон Æмбырды Паддзахадон Думæ";

- The Department of public health, communications and expert activity Ministry of Healthcare of the Russian Federation "Уæрæсейы æнæниздзинад хъахъхъæнынады министрады коммуникациты æмæ æхсæнадон æнæниздзинады департамент";

- Department for relations with Faith-Based Organizations "Дины организацитимæ æмгуыстады Департамент";

- Committee of Parliament on budget, taxes, property and credit organizations "Парламенты бюджеты, хъалонты, исбонад æмæ кредитон организациты комитет";

- Committee of the Parliament on legislation, legality and local self-government "закъонæвæрынады, закъонад æмæ бынæттон хиуынаффæйады комитет";

- Federal Health Care Supervisory Agency "Æнæниздзинад хъахъхъæнынады къабазмæ цæстдарды федералон службæ";

\section{The names of the funds:}

- Exhibition Fund of the Republic of North Ossetia-Alania "Республикæ Цæгат ИрыстонАланийы равдыстыты фонд";

- Fund "Russian world" "Фонд "Уырыссаг дуне"";

- Health Insurance Fund "Æнæмæнг медицинон фæдзæхстады федералон фонд"; 


\section{The names of health care institutions:}

- Republican center of medical prevention "Медицинон профилактикæйы республикон центр";

- The North Ossetian branch of the Russian Red Cross "Сырх Дзуары комитеты РЦИАланийы хайад";

- The North-Caucasian Multifaceted Medical Centre (Beslan) "Беслæны бирæкъабазджын медицинон центр";

- Blood transfusion station "Тугдæттæн станцæ".

Many difficulties are caused by expressions included in the thematic category "Names of historical events and holidays". They are caused by a different word order than in Russian. For example:

- The day of military glory of Russia "Уæрæсейы хæстон намысы бон";

- All-Russian print day "Мыхуыры æппæтуæрæсеон бон";

- All-Russian day of science "Наукæйы æппæтуæрæсеон бон";

- International Mother Language Day "Мадæлон æвзаджы æппæтдунеон бон";

- Defender of the Motherland Day "Фыдыбæстæ хъахъхъæнæджы Bon", etc.

However, not all the names of this group are built in this order. There are others, for example, the combination "First World War" is translated in Ossetian in the same order - "Фыццаг Дунеон хæст".

In the modern Ossetic language media space, combinations of words are often used, which are necessary to enter into lexicographic publications, since it would be difficult to carry out document management without such cliched expressions.

- will be performed "æххæстгонд æрцæудысты";

- as part of the month "мæйоны фæлгæты";

- in connection with the necessity of "æвæстиат уавæртимæ баст";

- in pursuance of the federal program "федералон программæтæ æххæстгæнгæйæ";

- second reading "дыккаг бакаст";

- highest awards "уæлдæр хорзæхтæ";

- government award "паддзахадон хорзæх";

- cooperation agreement "æмгуыстады бадзырд";

- award ceremony "хорзæхджын кæныны церемони", etc.

Their neogenicity is not obvious, but their absence in dictionaries reduces user interest and complicates the process of business communication, in particular, the preparation of business letters and other documents.

The language trend of recent months is the entry of a significant number of lexical units semantically related to the news dominant - the pandemic-into the Russian language as a whole and into the vocabulary of management activities. The ways of neologization and mechanisms of word-formation are traditional: borrowing and proper means of the language (calques, half-calques, word formation), less 
often new words, and stable combinations appear due to the reinterpretation of the meaning of existing words.

The study results showed that the media discourse content from March to May 2020 has undergone significant changes, expressed in the flooding of the Russian and Ossetian languages with medical terminology and vocabulary close to the medical industry.

The Ossetic language has also recently included many lexical units related to the pandemic. Some of them are borrowings from English through Russian, while others are words and expressions created using the Ossetic language itself. For example:

- ног коронавирусон низ "new coronavirus disease": "Цæгат Ирыстонмæ стахт мæскуыйаг дохтырты бригад бынæттон медицинон кусджытæн сæ фæлтæрддзинадæй баххуыс кæнынмæ. Уыдон куыстой Мæскуы æмæ мæскуыйаг облæсты рынчындæтты, ног коронавирусон низæй адæмы дзæбæх кодтой» (Newspaper "Рæстдзинад", 2020) - "А team of Moscow doctors flew to North Ossetia to share their experience with local medical professions. They worked in hospitals in Moscow and the Moscow region, treating people for a new coronavirus disease";

- тæссаг зонæ "affected area": "Йæ ныхæстæм гæсгæ, къорды ис реаниматолог, инфекционист, пульмонолог, компьютерон томографийы дохтыр. Уыдон иууылдæр куыстой тæссаг зонæйы» (Newspaper "Рæстдзинад", 2020) - "According to him, the group has a resuscitator, an infectologist, a pulmonologist, a specialist in computerized tomography. All of them worked in the affected area";

- хи бахъахъхъæныны фæрæзтæ "personal protective equipment": "Æнжниздзинад хъахъхъæнынады министрадæй куыд фехъусын кодтой, афтæмæй мæскуыйаг дохтыртæ семæ сластой ног хæцгæниз дзæбæхгæнæн хостæ, нæ рынчындæтты кусджытæн хи бахъахъхъæныны фæрæзтæ» (Newspaper "Рæстдзинад", 2020) - "As reported in the Ministry of Health, Moscow doctors brought medicines for the treatment of a new infective disease, personal protective equipment for hospital workers";

- коронавирус низæфтауæг "coronaviral infection": "Коронавирус низæфтауæг кæмæ рабæрæг, уыцы цæгатирыстойнæгты нымæцыл фæстаг суткæйы дæргыы бафтыд 51 адæймаджы» (Newspaper "Рæстдзинад", 2020) - "The number of people infected with coronaviral infection in North Ossetia over the past day has increased by 51 people";

- хииппæрддзинады фæткмæ гæсгæ архайын "observe the lockdown", дохтырты цæстдарды бæрны уын "be under the screening of doctors": "Уымæй уæлдай, хииппæрддзинады фæткмæ гæсгæ чи архайы æмæ дохтырты цастдарды бæрны чи ис, уыцы адæмы нымæц абоны онг у 1151» (Newspaper "Рæстдзинад", 2020) - "Also, the number of those who observe the lockdown and are under the screening of doctors today is $1151 "$.

The list of neologisms also includes the expressions "медицинон цæстдардæй сисын" (remove from medical screening), "карантины мадзæлттæ фæрогдæр кæнын" (weaken containment measures), etc. 


\section{Conclusion}

Summing up, we note the sufficient activity of the Ossetic language in producing constructions that replace borrowed words in official speech and the field of document support of management. This is evidenced by numerous examples from the Ossetian media space. In recent times, the Ossetic language continues to be an effective communication system that can respond to the needs of modern society.

\section{Acknowledgments}

The reported study was funded by RFBR according to the research project \#18-012-00440 "Active processes in vocabulary of multi-structural languages: internal development and external interaction".

\section{References}

Gatsalova, L. B., \& Parsieva, L. K. (2015). Possibilities of terminological interpretation and lexicographical reflection of the potential words. Science Journal of Volgograd State University. Series 2: The Linguistics, 4(28), 138-143.

Gatsalova, L. B., \& Parsieva, L. K. (2019). Lexis of management activity in the Ossetic language: a textbook with a Russian-Ossetian dictionary-a minimum of terms for document support of management. Vladikavkaz.

Gureeva, A. A., Novikova, E. Y., \& Mityagina, V. A. (2016). Guide-interpreter's language identity as an excursion discourse factor. XLinguae, 9(2), 90-102.

Ilyin, D. Yu., \& Sidorova, E. G. (2019). Onomastic lexicography in the aspect of the lingua-ecological approach. Science Journal of Volgograd State University. Series 2: The Linguistics, 18(4), 174185.

Ilyin, D. Yu., \& Solomka, N. A. (2018). Principles of meaning creation of denominative verbs. Science Journal of Volgograd State University. Series 2: The Linguistics, 17(2), 74-81.

Isaeva, Z. G., \& Isaev, M. I. (2010). Interaction of the Russian language with the languages of the Iranian peoples of the CIS. Issues of Philology, 1(34). http://journal.mosinyaz.com/page_48_34/

Kudzoeva, A. F. (2014). The Ossetic language and culture of Speech. Vladikavkaz.

Mityagina, V. A. (2014). Translation in the formation of tourist Internet discourse. In Media and intercultural communication in the European context. Materials of the International research and practice conference (pp. 346-348). Stavropol.

Morgoeva, L. B., \& Tsallagova, I. N. (2018). Influence of semantic transformations of dialect lexical items on the formation of conceptual domains. Proceedings of NOIHSS, 30(69), 83-94.

Morgoeva, L. B., \& Tsallagova, I. N. (2019). Dialect polysemia as a source of interpretation of language signs. Advances in social science, education and humanities research Proceedings of the International Conference "Topical Problems of Philology and Didactics: Interdisciplinary Approach in Humanities and Social Sciences" TPHD 2018, 332-335.

Newspaper "Рæстдзинад" (2020, June 5). https://xn--80aalbng9atkk.xn--p1ai/2020/06/05/rynchyntyuavaermae-baeston-tsaestdard-aeppaet-kaephaentyl-daer.html

Newspaper "Рæстдзинад" (2020, Мау 29). https://xn--80aalbng9atkk.xn--p1ai/2018/08/22/ekonomikonraezty-dardaemguydmaejy-nysantae-nog-ahuyradon-az-aemae-aendaer-ahsdzhiag-farstatae.html

Novozhilova, A. A., Korolkova, S. A., Gureeva, A. A., Shovgenina, E. A., \& Mityagina, V. A. (2015). Creating information retrieval competence of future translators: an integrative approach. Mediterranean Journal of Social Sciences, 6(6), 79-84.

Senko, E. V. (2019a). Connotative-pragmatic dynamics of eastern borrowings in modern Russian. Actual problems of philology and pedagogical linguistics, 2, 111-119. 
Senko, E. V. (2019b). The functional dynamism of the modern Ossetian lexis. Tomsk journal of linguistic and anthropological research, 4(26), 39-47.

Senko, E. V. (2019c). Language analytization as a transformation mechanism of reality conceptualization. The European Proceedings of Social \& Behavioural Sciences EpSBS, SCTCGM 2018, 1122-1129.

Tsopanova, R. G., Gatsalova, L. B., Kudzoeva, A. F., Gazdarova, A. Kh., \& Khozieva, I. Kh. (2019). Colour naming in Ossetian language: linguocultural aspect. The European Proceedings of Social \& Behavioural Sciences EpSBS, SCTCGM 2018, 2024-2031. 